\title{
A Quest for Technological Competence: Raising the Bar
}

Doug Surtees <doug.surtees@usask.ca>

Craig Zawada <craig@zawada.ca $>$

SASKATOON, Canada

\section{Abstract}

The necessity for legal professionals to acquire and maintain a minimum standard of technological competence for lawyers has never been higher. Regulators of the legal profession in several jurisdictions have imposed a duty of technological competence on lawyers. The authors argue that law societies and law schools have an obligation to work together to include appropriate technological education in law school. This requires teaching not only Law of Technology (LOT) concepts such as Intellectual Property but also Law Practice Technology (LPT) concepts.

\section{Keywords:}

educating lawyers, technological competence, tech competence

technological education, tech education, tech ed, lawyers' duties, code of conduct, law of technology, law and tech, law practice technology, law practice tech, law school curricula, law school reform, continuing legal education, legal ed, law society duty, legal education reform, legal ed reform, legal education, legal ed, professional development

Lawyers are the original knowledge workers. An absolute statement like this invites debate and disagreement. Other professions depend on their own specialized know-how, after all. But there is no doubt that law rests almost entirely on information and its application.

So it is odd that lawyers have not been the vanguard of the Information Age. Somewhat the opposite, actually. Law and lawyers have been criticized for not keeping up with the internet, mobile computing and 
other commonplace technologies. ${ }^{1}$ Despite its reliance on information and its application, the legal profession has not been a high-tech leader.

The landscape is not entirely bleak. Some lawyers' codes of conduct have adopted a duty of technological competence. The American Bar Association approved a such a duty in 2012. It has since been implemented by a majority of US states. The Federation of Law Societies of Canada's Model Code added a comparable duty in 2019. It has been adopted by several Canadian jurisdictions. This duty now exists on the same plane as duties of confidentiality, civility and other fundamental elements of ethical legal practice.

Mandating a duty is just the first step. Although the ultimate result could be sanctions and penalties for non-compliance, that is clearly not the goal. ${ }^{2}$ The purpose of adopting the duty at the outset was undoubtedly to elevate lawyer skills so they were "competent" ${ }^{3}$ when delivering services in the Information Age.

Competence does not just happen. All skills required by codes of conduct, regulator rules or otherwise rely on an infrastructure to provide sufficient education and training to learn those skills. The duty of technological competence is no different.

All participants in the education of legal practitioners have a responsibility to support the new duty. This includes not only the regulators, through their continuing professional development (CPD) programs, but also law schools and private providers of legal training. This paper will review the new requirements, the delivery of legal education in Canada, and barriers to bringing technology education into the current system.

1 Jordan Furlong, Law is a Buyer's Market: Building a Client-First Law Firm (Law21 Press 2017) 60

2 Many regulators, including the Law Society of Saskatchewan, have intentionally moved to a first mindset of coaching rather than discipline. This recognizes that prevention is usually easier than remedy, and that the ultimate goal is not penalties but public protection.

3 Measuring competence is fraught with issues, and they will not be discussed here. 


\section{Adoption of a Duty of Technological Competence}

The list of reasons cited to require lawyers to possess a duty of technological competence includes: ${ }^{4}$

- The constant need to maintain and improve efficiency when delivering legal services

- Client and societal demand for modern delivery of services

- The increasing digitalization of society's institutions and their delivery of services

Technology related issues, including such diverse topics as blockchain, privacy and intellectual property protection have emerged in all legal fields. In response, the Federation of Law Societies of Canada (FLSC) adopted a duty of technological competence in October, 2019.5 The FLSC is the national coordinating body of the 14 law societies mandated by provincial and territorial law to regulate Canada's 130,000 lawyers, Quebec's 3,800 notaries and Ontario's 11,300 licensed paralegals. The FLSC maintains a Model Code of Professional Conduct. This Code has been implemented in whole or part by most Canadian law societies, including our home jurisdiction of Saskatchewan. ${ }^{6}$

In November, 2019, the Law Society of Saskatchewan adopted changes to its Code of Professional Conduct based on the Model Code. The language adopted in Saskatchewan reads:

$3.1-2 \ldots$

[4A] To maintain the required level of competence, a lawyer should develop an understanding of, and ability to use, technology relevant to the nature and area of the lawyer's practice and responsibilities. A lawyer should under-

4 See $<$ https://flsc.ca/wp-content/uploads/2014/10/Consultation-Report-Draft-Model -Code-Amendments-for-web-Jan2017-FINAL.pdf $>$ accessed 1 September 2021. See also Stacey Blaustein, Melinda McLellan and James Sherer, 'Digital Direction for the Analog Attorney-Date Protection, E-Discovery, and the Ethics of Technological Competence In Today 's World of Tomorrow'(2016) 22, 4, 1 Richmond Journal of Law \& Technology.

5 The addition was added as a Commentary item to the existing duty of competence: "A lawyer must perform all legal services undertaken on a client's behalf to the standard of a competent lawyer."

6 Saskatchewan is one of 10 provinces which, along with 3 territories, form the Canadian federation. Like all other provinces and territories (except Quebec, which implements a dual common law / civil law system), Saskatchewan is a common law jurisdiction. 
stand the benefits and risks associated with relevant technology, recognizing the lawyer's duty to protect confidential information set out in section 3.3.

[4B] The required level of technological competence will depend upon whether the use or understanding of technology is necessary to the nature and area of the lawyer's practice and responsibilities and whether the relevant technology is reasonably available to the lawyer. In determining whether technology is reasonably available, consideration should be given to factors including: a) The lawyer's or law firm's practice areas; b) The geographic locations of the lawyer's or firm's practice; and c) The requirements of clients.

As of May, 2021, many Canadian regulators have adopted the Model Code changes, or issued separate practice advisories. ${ }^{7}$ These changes followed similar additions to the American Bar Association's Model Rules of Professional Conduct. Comment 8 to Model Rule 1.1 was amended in 2012 to add the emphasized text:

To maintain the requisite knowledge and skill, a lawyer should keep abreast of changes in the law and its practice, including the benefits and risks associated with relevant technology, engage in continuing study and education and comply with all continuing legal education requirements to which the lawyer is subject. ${ }^{8}$

As of May, 2021, 39 US states have formally adopted the revised Comment. At least one other state (California), while not formally adopting the Comment, has issued an ethics opinion requiring the duty. ${ }^{9}$

The passage of regulations creating a duty of technological competence establishes a specific requirement which will require attention by all lawyers, and upgrading by some. We will have to wait for future interpretation of the regulation to fully define its scope. The duty, however, has arrived.

7 For example, Saskatchewan, Alberta, Nova Scotia, Manitoba and Yukon Territory adopted the FLSC commentary. Other jurisdictions, including Ontario and Northwest Territory, have issued guidance on technological competency.

$8<$ https://www.lawsitesblog.com/tech-competence> accessed 1 September 2021.

9 ibid. 


\section{Legal Education in Canada}

The education of lawyers typically combines elements of academia, regulator-sponsored CPD ${ }^{10}$ and private training. For most lawyers, ${ }^{11}$ the process begins with a University education. Law school applicants generally require a minimum of 60 university level credit units. This is equal to two years of full-time study. All Canadian law schools have many more applicants than seats available. As a result, many applicants have completed one or more university degrees prior to being accepted as a law student. The typical law school program is three years, with law schools accredited by the FLSC.

Following law school convocation, would-be lawyers must complete articles of clerkship. This normally involves a year-long engagement with a private law firm, or lawyer. ${ }^{12}$ Alongside this articling period, the prospective lawyer must successfully complete a bar admission course, typically administered by the relevant law society. The length, content and format of this course differs among jurisdictions. After completing articles and the bar admission course, the individual is eligible for admission to the law society as a full member.

All lawyers are entitled to practice virtually any type of law and act for any client. However, few lawyers would consider themselves fully proficient upon admission. Depending on circumstances including the areas of law, it may be years before someone would be considered fully "competent." 13 The training in that period is a combination of the continuing professional development (CPD) provided under the auspices of the regulator, as well as on the job instruction and mentoring received while providing legal services to clients. Ideally, lawyers are life-long learners.

10 The Law Society of Saskatchewan provides many hours of CPD opportunities through in-person and online instruction, some free and some fee-based. Members can pick and choose topics of interest, subject to a requirement of a minimum number of hours annually. In addition, lawyers can take courses from other providers, or prepare their own programs, with LSS approval. While details vary, most Canadian jurisdictions operate under a similar framework.

11 Canada does offer a program, the National Committee on Accreditation, which permits lawyers from other countries or who have obtained civil law accreditation, to obtain the right to become law society members without attending a Canadian law school.

12 Articles can also be served with various courts or government justice ministries.

13 Of course, depending on the level of self-awareness or self-doubt, some might never consider themselves at a required level. 
The merits and disadvantages of this educational system are open to debate, but there are obviously many opportunities available to upgrade and obtain necessary skills. One striking feature is the importance of experiential training, usually through private sources such as law firms. Law firms can enhance their market competitiveness by providing its lawyers with a high level of education and experience, including in technology.

There are also incentives for the academy and the regulator to enhance further technological competence. Regulators strive to reduce discipline in their role of protecting the public interest. Enhanced technological skills in lawyers will assist in this goal. Law schools seek to graduate the best students from their programs. Law schools can enhance their reputation by teaching their students greater technology skills.

But these considerations may not be enough to guarantee the new duty is properly embraced, with enough content to ensure both new and existing lawyers possess the minimum skills required by Codes. It is important for educators and regulators to recognize their responsibilities in providing education in all critical competencies, including technology.

The existing landscape is obviously not barren. There are already courses and CPD offerings in certain aspects of technology. For example, the Law Society of Saskatchewan and the University of Saskatchewan's College of Law have recently partnered in a program to educate students in practice matters, including technology. ${ }^{14}$

Law schools might also argue that the increasing impact of the Information Age has led to new technology courses. This may be true, but it is also important to recognize the difference between courses on the law of technology (LOT) and those on law practice technology (LPT). Both are important, but they are not the same.

LOT courses have existed for many years. These courses include topics such as intellectual property and licensing. In recent years, schools have created courses on emerging technologies such as blockchain, biotechnology and internet law. ${ }^{15}$ Some of these topics, such as the integration of blockchain into smart contracts, make their way into traditional law courses like Contract Law. While important, these classes do not directly impact the duty of technological competence. In fact, it may be that

14 This course, Transformation in Practice: Building the Future Lawyer, began in the Winter term of 2021.

15 Examples include the Osgoode Hall Certificate in Blockchains, Smart Contracts and the Law, Harvard's cluster of courses devoted to Health Law, Biotechnology, and Bioethics, and Stanford Law School's Center for Internet and Society. 
students taking such courses are above the norm in technical knowledge and would already meet the newly prescribed duty.

It is the LPT courses which are more aligned with the new duty of technological competence, since they deal with actually using and benefiting from technological aids. These courses might teach something as fundamental as the various e-discovery packages for purposes of a civil litigation practice. They might be specifically aimed at enhancing all aspects of technology use in a law practice, ranging from accounting to document management, client management and more. There has been some resistance to including these courses in the standard law school curricula. However, as law schools incorporate concepts of LPT courses, their graduates will enter the profession with a significantly higher baseline of knowledge. This in turn will support the development of adequate knowledge by all lawyers.

\section{Challenges}

While few would challenge the desirability of providing law students and lawyers more education on using relevant technology, there are obstacles to overcome. One impediment is simple conservatism. Lawyers are often criticized for being change-averse, perhaps a consequence of being immersed in a profession which literally depends on precedent. They do not have a monopoly on traditionalism, however. The academy also changes slowly. An often bureaucratic administrative structure and huge sunk-cost investments are two factors mitigating against rapid change. In fairness to these institutions, humans are generally not change-receptive at the best of times. Moving from the status quo represents a risk.

There are other challenges to change. Law professors tend to stay in their position for many years. Not all professors practised law before becoming full time law teachers. Professors being hired today are more likely to hold a doctorate than in the past. Individuals with a doctorate have clearly demonstrated their academic credentials, but this is not the same thing as practicing law. Many law professors have not practiced law in a way, or at a time, which required the technologies being explored in LPT courses.

There are also resource issues, particularly as post-secondary institutions around the world struggle with rising costs and indifferent public funding. Creating new programs requires funds.

We will address five typical arguments likely to be put forth as reasons to not move forward with enhancing education on technological compe- 
tence: the 'trade school' objection; the 'competing resources' objection; the 'limited faculty' objection; the 'ever-changing technology' objection and the 'difficulty in measuring competence' objection.

\section{The Trade School Objection}

Law schools and the legal profession seem to have a close relationship, given the former's role as the principal source of new lawyers. The actual situation, however, is more nuanced.

Law schools exist in an academic setting and are not merely factories producing lawyers. The law school atmosphere is highly theoretical. The partnership forged over many decades has law school primarily focused on providing students with an academic education rich in theory and including a robust exchange of ideas, while the profession, through articling and bar admission courses, has primarily focused on teaching individuals the practice skills they need to be effective lawyers. A lawyer's education is received partly through law school and partly through articles and postgraduation professional development courses. But this does not mean the law school and the regulator need be in conflict.

Casting the relationship between law schools and regulators as a choice between whether a law school education should be academic or practical does a disservice to law schools and regulators, as well as to the concepts of 'academic' and 'practical' education. Law schools and regulators certainly do look through different lenses, and it is true their interests or objectives do not always align. However, they share a common goal that law school education be "both intellectually rigorous and professionally useful." 16

The law school journey is intimately concerned with teaching skills, but not necessarily teaching practice skills. Consider a Wills and Estates class as an example. Such a course would typically consider the various ways in which jurisdictions provide for the orderly transfer of property upon a person's death. Matters including Will validity, correction of errors, Wills interpretation issues, obligations to dependents, and admissibility of evidence would be considered. Successful students would gain the skills and knowledge to recognize common Wills issues and be able to identify relevant legislation in their jurisdiction. In short, students would be 'functionally literate' in Wills in that they would know how to learn to adminis-

16 Beth Bilson, 'Prudence Rather than Valor: Legal Education in Saskatchewan 1908-23’ (1998) 61 Sask L Rev 341, 342. 
ter an estate in various jurisdictions and would have the skills to adapt to changes in the law. No competent law school would consider a Wills and Estates course complete if it solely consisted of teaching students how to complete probate forms in its jurisdiction - although some exposure to those forms, or at least awareness that such forms exist would presumably be useful to students.

Similarly, LPT courses must provide students with the skills and knowledge required to not only identify common LPT issues, but also to be functionally literate using that technology. This means they would not only be familiar with examples of LPT, but would also know how to learn to become skilled with emerging technology. The law school mission and the regulator mission would both seem to support such outcomes. As with other areas, law school courses on LPT would be expected to take a broader, more academic approach whereas professional development courses would likely have a somewhat more practical approach. The approaches are complementary, and each has a role in developing competent lawyers.

A competent lawyer must understand substantive law, interpret and communicate complex principles, and demonstrate empathy and mental resilience. We are not diminishing any of these elements. Our point is that technological competence is also a critical skill. This is particularly so in the Information Age when IT tools are augmenting or replacing traditional lawyer functions.

Law schools and regulators should not see themselves in a 'turf war' where one defends academic standards and the other promotes lawyer skills. To do so would miss the point that the ground being contested is not theirs. The real purpose of educating lawyers during and after law school is to provide legal assistance to citizens. It is their interests which are paramount. Lawyers are a means to that end.

The proper educational balance between theory and skill development depends upon purpose. There may be a range of views as to the best place to draw the precise line. In truth, it is impossible to train lawyers without a healthy dose of substantive law and training in delivery of information. Law schools have always tried to bridge this divide. There are already many examples of classes at every North American law school that go beyond substantive law into technique and practical matters. ${ }^{17}$ The real question is where the balance should rest.

17 For example, courses on negotiation, awareness of Indigenous issues and clinical programs for delivery of legal services to underserved populations. 
That balance will always be shifting. Given the importance of information technology to all phases of society and everyday life, it is hard to argue against providing at least a modicum of such knowledge for lawyers. The duty of technological competence cements this necessity. It is simply inconceivable that technology will become less important in everyone's lives. Lawyers must not only accept it, but be able to benefit from it.

\section{Competing Resources}

A common objection to adding anything to law school curricula is that there is no available time or financial resources to support new initiatives. Introducing LPT courses comes down to priorities. Is technological competence as important as, say, learning criminal law?

The law school curriculum and pedagogy has changed over recent decades. This change has been driven in part by a recognition of the evolving needs of lawyers and society. ${ }^{18}$ Most law schools have avoided a 'one-size fits all' approach to legal education. This is appropriate as not all law graduates practice law, and those who do have a tremendous variance in the scope of their practice. ${ }^{19}$ While it is difficult to compare the importance of any substantive area against others, an ongoing assessment of the appropriate concentration of various topics is necessary to avoid stagnation. We submit that technological competence exists on a plane above most substantive law. It covers all practice areas and practitioners. If the goal is universal utility, a far better case can be made for the need to understand technical aids over many substantive areas which a lawyer may never experience in their career. In other words, technology cannot be viewed in isolation. It infuses itself into literally all facets of society, and all substantive areas of law. This means that courses outside of LPT should incorporate technology instruction into their syllabi. Examples include teaching online platforms in an alternative dispute resolution course, or blockchain and smart contract technology in a contracts course.

18 James R Maxeiner, 'Educating Lawyers Now and Then: Two Carnegie Critiques of the Common Law and the Case Method' (2007) 35 Int'l J Legal Info 1.

19 Most regulators do not restrict new lawyers from practicing any area of law, whether or not they were trained on the subject. This "murder to merger" practice model is in itself a competency issue which regulators have not yet been able to adequately handle -but this issue is beyond the scope of this paper. 


\section{Limited Faculty}

The world seems to be divided into two types of people: those who revel in technology, and those who put up with it. For every person who delights in technology for its own sake, there are others who only want to use technology to get things done, without understanding bits, protocols and internet minutiae.

This impacts teaching in a couple of ways. For one, if we are trying to integrate technology into existing courses like civil procedure or contracts, teachers with knowledge in those topics might not have sufficient technology skills to teach those aspects. There is no inherent intersection between knowledge of contracts and knowledge of blockchain. An expert in the former may be completely illiterate in the latter. This does not mean they are a poor contracts educator. They may be world-renowned in the substantive topic, but they could benefit from introducing guests with specific knowledge and skills. A benefit of the massive increase in online teaching during the Covid-19 epidemic was the increased use of guest lecturers, including non-local teachers. Devoting a class or two to specific technology in a substantive area, with world-class experts who deliver the information remotely, has proven to be an effective way to supplement the substantive law skills of classroom instructors.

Introducing dedicated LPT courses presents a different challenge. Only the most fortunate law schools will have the ability to hire additional instructors with both a deep understanding of technology as well as familiarity with the substantive law.

Many law schools may address this challenge through the use of adjunct professors. ${ }^{20}$ LPT courses by definition involve practice matters. The melding of substance and practice is a fundamental aspect of these courses. Lawyers with a working knowledge of the technology itself can be extremely effective educators.

\section{Changing Technology}

Another objection raised to teaching technological competence is the evershifting terrain of technology itself. Although there has always been a progression of tools, and obsolescence of old ways of doing things, this has

20 Sometimes referred to as sessional lecturers in Canada. For these purposes, an adjunct/sessional is a person, often a lawyer, who is not part of tenured faculty and is paid on a per-course or per-student basis. 
accelerated in the Information Age. Legacy support of old technologies can adapt to a point, but new paradigms arise which kill old ways of doing things.

This will never change. New ways of doing things inevitably arise. Sometimes they are evolutionary and adaptation is in order. In other cases a revolutionary advancement requires an entirely new mindset and set of skills to cope. This has happened with the printing press, the photocopier and the fax machine. The difference today is in the speed of change, and the shrinking life cycles of products. While we used fax machines for 3 or 4 decades, newer technologies may be measured in years or even months.

The answer is obvious. We cannot stem the advancement of technology, in law or society as a whole. We must embrace the mindset that change will happen and we must be flexible enough to accept and implement the change. Individuals adapt to technologies at varying speeds. Wherever teachers, students, lawyers and regulators are along this innovation adoption curve, ${ }^{21}$ a key concept in technological competence courses is that we must accept that change will occur, and we must adapt.

This requires teaching concepts rather than specific technologies. This does not mean ignoring the tools themselves. Technology such as word processing and collaborative software packages like Microsoft Teams will be around a long time, at least long enough to make it worthwhile to learn about them. But getting comfortable with technology concepts inherent to the internet and mobile computing, to use a couple of examples, is critical in competence education.

\section{Measuring Competence}

Objectors to the addition of technological competence emphasize the difficulty of measuring capabilities. Even in the vaguely worded duties adopted in Canada, one wonders how a meaningful assessment of a minimum standard can be achieved.

Every aspect of legal competence is subject to the same objection. How does one measure substantive law knowledge, or ability to communicate information to clients? The former is arguably assessed through law school

21 See Joe M. Bohlen and George M. Beal 'The Diffusion Process' (Special Report No. 18. 1, Iowa State College, May 1957) 56-77, where the authors categorized users of new innovations as innovators, early adopters, early majority, late majority, and laggards. 
and bar course exams, ${ }^{22}$ but there are no meaningful ongoing testing procedures in place in Canada or most other jurisdictions. This is not just a legal education problem. ${ }^{23}$ However, the difficulty of valid and reliable competency measurement is not an excuse to avoid teaching technological competence. We ought to teach it, and we ought to strive to develop valid and reliable competency evaluation tools. Perhaps if we are successful in the second of these, we will improve our ability to evaluate all strata of competence. There may be nothing inherently different about measuring technological competence from measuring other skill-based competencies. A new rigor applied to evaluating technological competence may provide a lesson of how to perform assessment of other types of lawyer competence.

\section{Conclusion}

It is beyond the scope of this paper to describe what a well-formed system teaching life-long technological competence would include. We would suggest that legal educators and regulators must work together to create such a system. Law schools can benefit from the expertise of practitioners and regulators as they seek to imbed such education within the law school. Practitioners and regulators can benefit from legal educators embracing the goal of providing appropriate LPT and LOT education as a standard part of a law school education.

The competence of legal practitioners is at the heart of legal education, legal practice and the regulatory system which oversees it. The public interest depends on knowledgeable practitioners delivering sufficient legal services. The hardware and software that form the backbone of the Information Age is a critical category of knowledge necessary for competence. As law societies and legal educators recognize this, they must also recognize their respective obligations to actively promote and supply that education.

22 Although it is also arguable that this measures only one's skill in writing exams or essays, not the actual work of being a lawyer.

23 There is a rich literature in evaluation and assessment in education generally, as evidenced by the wide variety of academic journals focusing on the topic. 
